\title{
Colon resection for endometriosis
}

\author{
Timuçin $\operatorname{Erol}^{1}$ (ID), Erhan Reis²(iD), Önder Koç3 (ID), Barış Taşbaş ${ }^{4}$ (iD) \\ 1 Department of General Surgery, Hacettepe University School of Medicine, Ankara, Turkey \\ 2 Department of General Surgery, Ankara Memorial Hospital, Ankara, Turkey \\ ${ }^{3}$ Department of Gynecology and Obsdetrics, Ankara Memorial Hospital, Ankara, Turkey \\ ${ }^{4}$ Department of Radiology, Liv Hospital, Ankara, Turkey
}

\begin{abstract}
Endometriosis affects the women during reproductive period and can cause functional disorders. Sometimes general surgical intervention is necessary because of disease boundary. Especially the sigmoid colon and rectum are affected due to the close neighboring. In such a case, treatment must be individualized according to the patient and symptoms. If the lesion has penetrated the entire bowel wall, bowel resection may be inevitable. Laparoscopic resection of the sigmoid colon or rectum can be performed safely in this situation. When laparoscopic resection cannot be possible because of technical difficulties, open resection may be performed for treatment. Here we present two cases, one open and one laparoscopic colon resection performed due to endometriosis.
\end{abstract}

Keywords: Endometriosis, colon resection, hysterectomy

Cite this article as: Erol T, Reis E, Koç Ö, Taşbaş B. Colon resection for endometriosis. Turk J Surg 2019; 35 (4): 325-328.

\section{Corresponding Author}

Timuçin Erol

E-mail: timucinerol@yahoo.com

Received: 13.01 .2018

Accepted: 19.03.2018

Available Online Date: 16.12 .2019

OCopyright 2019 by Turkish Surgical Society Available online at www.turkjsurg.com

DOI: 10.5578/turkjsurg.4054

\section{INTRODUCTION}

Endometriosis, the presence of endometrial cells outside of the uterine cavity, is a benign condition which affects women during the reproductive period (1). This disease affects approximately $10 \%$ of the general population, and $25 \%-50 \%$ of the infertile women suffer from this condition (2,3). Treatment must be individualized according to the patient's age, fertility status, symptoms and extensity of the disease. Full-thickness excision, shaving or resection are the treatment of choice in case of bowel involvement. This study aimed to present two cases of deeply infiltrative endometriosis treated by hysterectomy, oophorectomy, and anterior resection due to bowel involvement which causes luminal narrowing.

\section{CASE REPORTS}

\section{Case 1}

A 39-year-old female was admitted to the gynecology clinic because of menstrual pelvic pain and constipation. The patient's medical history included medical treatment and four times open surgery for deeply infiltrative endometriosis. Pelvic magnetic resonance imaging revealed multiloculated cystic mass with a close neighboring to the sigmoid colon (Figure1,2).

As the patient stated that she had completed childbearing and desired voluntary sterility, total abdominal hysterectomy, bilateral salpingo-oophorectomy and anterior resection were performed. Patient's postoperative course was uneventful and was discharged from hospital postoperative on the sixth day. The pathology report was compatible with endometriosis invading the serosa, subserosa and muscular layers of a colon. Colonic mucosa was intact. One year after surgery, the patient has no complaints. 


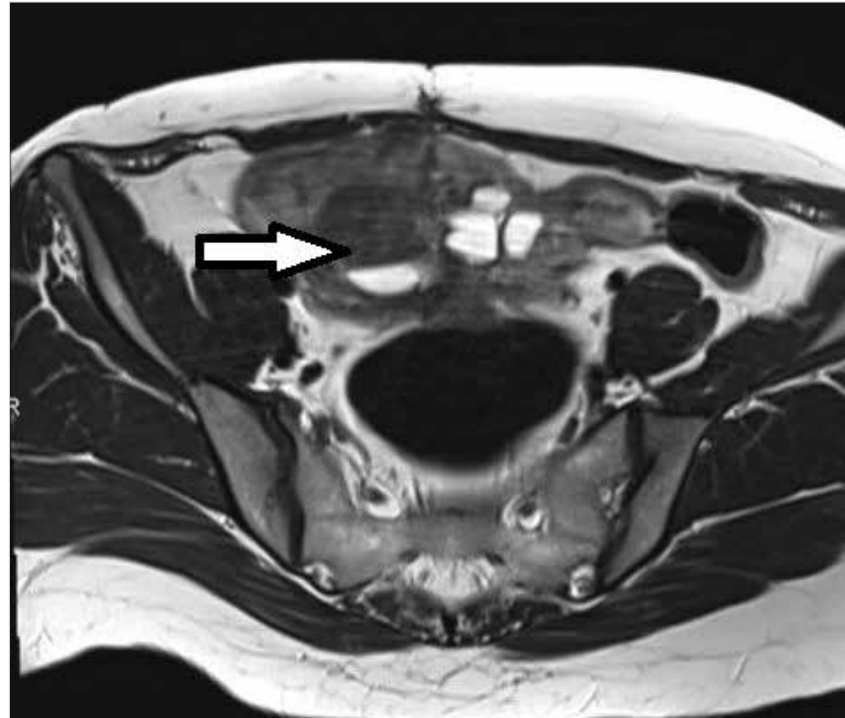

Figure 1. Ax T2: Heterogenous, hyperintense, multiloculated complex cystic mass is present. The fat plane effected between the cyst and the neighboring sigmoid colon and uterus.

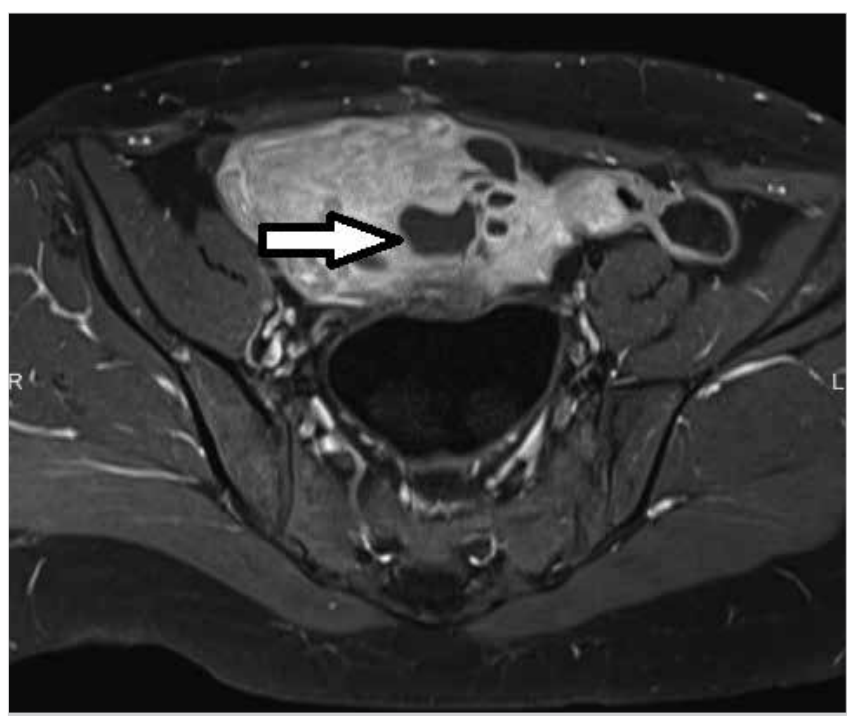

Figure 2. Ax T1: postcontrast FS T1: Image shows the linear enhancement of the walls of the multiloculated cystic mass.

\section{Case 2}

A 42-year-old female was admitted to the gynecology clinic because of a recently diagnosed right ovarian cyst. Laparoscopic right oophorectomy and bilateral salpingectomy were performed. Pathology result was endometriotic cyst for all specimens. Six months later, colonoscopy was performed due to constipation and bowel habit changes, and luminal restriction due to extrinsic compression was diagnosed. The colonoscope could not pass this restricted segment (Figure 3).

Magnetic resonance imaging showed loculated endometriosis focus which pushed the uterus anteriorly to a close neighboring with the colon (Figure 4,5).

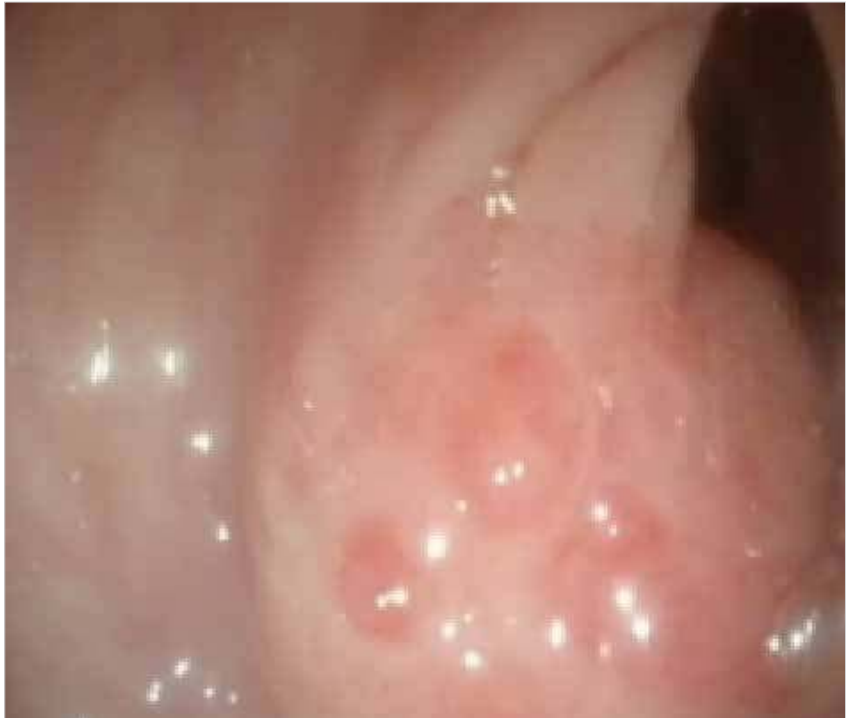

Figure 3. Appearance of colonic compression due to deeply invasive endometriosis during colonoscopy.

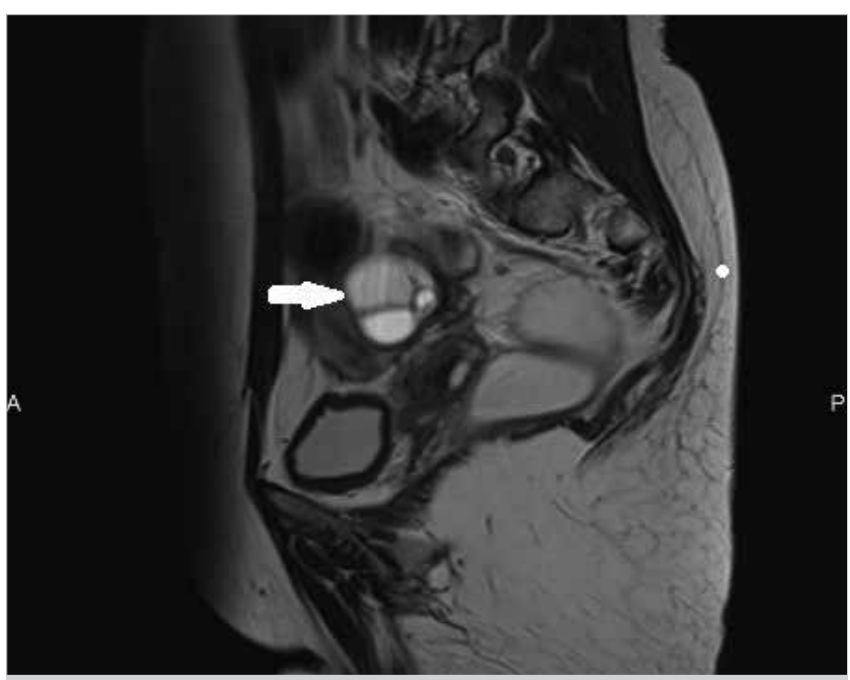

Figure 4. Sag. T2 WI: Cystic mass has T1 hyperintense T2 mild hyperintense, dense content at some locations.

As the patient stated that she had completed childbearing and desired voluntary sterility, laparoscopic hysterectomy, left oophorectomy and anterior resection were performed. Patient's postoperative course was uneventful and was discharged from hospital six days after surgery. Eight months after this operation, the patient was operated on for acute cholecystitis because of a recently diagnosed gall bladder stone, and during laparoscopic exploration, no endometriosis foci were present. The patient has no complaints two years after surgery. Pathology of the patient reported as endometriosis restricting the colon lumen at two different points.

Informed consent obtained from both of the patients. 


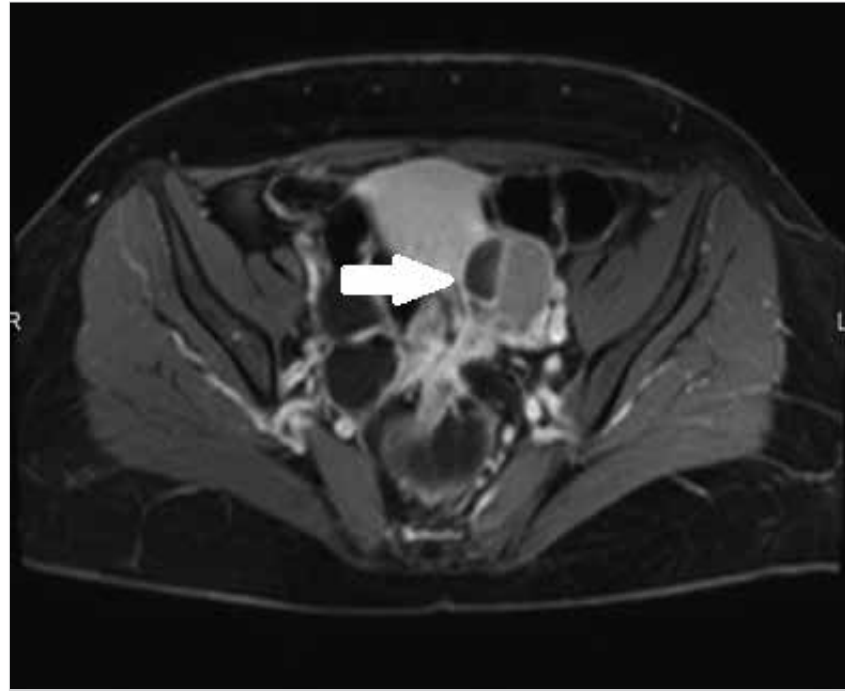

Figure 5. Ax, postcontrast T1 FS image: Linear wall enhancement at the dense loculated component. The mass pushes the uterus anteriorly.

\section{DISCUSSION}

Endometriosis has three clinical forms as peritoneal endometriosis, endometriotic ovarian cysts (endometriomas) and a deeply infiltrative form. Among these forms, deeply infiltrative endometriosis (DIE) is the most aggressive and problematic one.

DIE is defined as the infiltration of the peritoneum more than $5 \mathrm{~mm}$ (4). Pelvis is the most-frequent location and approximately $24 \%$ of the patients have sigmoid colon or rectum involvement (5). This disease can cause different symptoms, and treatment must be individualized according to symptoms, clinical condition and fertility status (6). Menstrual irregularities, dysmenorrhea, dyspareunia, chronic pelvic pain, mictalgia, and dyschezia are the main symptoms of deeply infiltrative endometriosis. In conjunction with these symptoms, involvement of the colon or rectum can cause functional disorders. Constipation, tenesmus, rectal bleeding or intestinal obstruction are some of these disorders which can be associated with bowel involvement $(1,7,8)$.

Surgery is a suppressive treatment for endometriosis if ovaries are left producing estrogen. Estrogen is the fuel of endometriotic focus. During the reproductive period, endometriosis tissue continues to grow if no hormonal treatment is applied. Its hormonal suppression using continuous dienogest or cyclic combined drospirenone and ethinyl estradiol is another option for treatment which also supports surgical therapy.

Endometriosis disease has 4 stages which produce obliterated cul de sac at stage 4. Endometriotic tissue at the rectovaginal septum is responsible for dyspareunia during intercourse. The probability of colonic involvement is high during stage 4 disease.

Stage 4 endometriosis may also affect the urinary tract in addition to the bowel involvement supporting a multidisciplinary approach for deep endometriosis surgery which includes gynecologist, general surgeon, and urologist.

Decision to perform surgery for DIE mainly clinical (4). Relieving pain and maintaining fertility with low recurrence rates are the main goals of endometriosis surgery for women during their reproductive period. However, for patients who have already completed childbearing, hysterectomy with or without bilateral salpingo-oophorectomy can be considered as an option for treatment (9). Although there is no guideline for patient selection or optimal treatment for DIE with colonic involvement full thickness excision, shaving or bowel resection are possible treatment modalities to remove the endometrioid foci and improve clinical outcome of the functional disorders (10-12). Clear indication of performing shaving or resection surgery is a matter of debate for centers of excellence studying endometriosis surgery. Although complication rates of bowel resection especially for lower rectal resections are higher, bowel resection can be suitable for lesions greater than $30 \mathrm{~mm}$ which cause obstruction or involve more than $1 / 3$ of the intestinal circumference (13). Laparoscopic sigmoid colon or rectal resection is possible and can be combined with gynecologic procedures safely.

\section{CONCLUSION}

Treatment of deeply infiltrative endometriosis with colonic or rectal invasion may be problematic. There is no guideline present for patient selection or treatment options in case of colonic or rectal invasion. Colon resection, laparoscopic or open may be performed in conjunction with hysterectomy and bilateral salpingo-oophorectomy for the selected patients who complete childbearing.

Informed Consent: Written informed consent was obtained from patients who participated in this study.

Peer-review: Externally peer-reviewed.

Author Contributions: Concept - All of authors; Design - All of authors; Supervision - T.E., E.R.; Materials - All of authors; Analysis and/or Interpretation - All of authors; Literature Search - T.E., E.R.; Writing Manuscript - T.E.; Critical Reviews - T.E., E.R., Ö.K.

Conflict of Interest: There is no conflict of interest for this study.

Financial Disclosure: No financial support received for this study.

\section{REFERENCES}

1. Wolthuis AM, Meuleman C, Tomassetti C, D'Hooghe T, de Buck van Overstraeten A, D'Hoore A. Bowel endometriosis: colorectal surgeon's perspective in a multidisciplinary surgical team. World J Gastroenterol 2014;20(42):15616-23. [CrossRef]

2. Evans $M B$, Decherney $A H$. Fertility and endometriosis. Clin Obstet Gynecol 2017;60(3):497-502.[CrossRef]

3. D'Hooghe TM, Debrock S, Hill JA, Meuleman C. Endometriosis and subfertility: is the relationship resolved? Semin Reprod Med 2003;21(2):24354.[CrossRef] 
4. Koninckx PR, Ussia A, Adamyan L, Wattiez A, Donnez J. Deep endometriosis: definition, diagnosis, and treatment. Fertil Steril 2012;98(3):56471.[CrossRef]

5. Haas D, Chvatal R, Habelsberger A, Wurm P, Schimetta W, Oppelt P. Comparison of revised American Fertility Society and ENZIAN staging: a critical evaluation of classifications of endometriosis on the basis of our patient population. Fertil Steril 2011;95(5):1574-8.[CrossRef]

6. Vercellini P. Introduction: management of endometriosis: moving toward a problem-oriented and patient-centered approach. Fertil Steril 2015;104(4):761-3.[CrossRef]

7. Acar T, Acar N, Celik SC, Ekinci N, Tarcan E, Capkinoglu E. Endometriosis within the sigmoid colon/extragenital endometriosis. Ulus Cerrahi Derg 2015;31(4):250-2.[CrossRef]

8. Arafat $S$, Alsabek MB, Almousa F, Kubtan MA. Rare manifestation of endometriosis causing complete recto-sigmoid obstruction: a case report. Int J Surg Case Rep 2016;26:30-3.[CrossRef]

9. Martin DC. Hysterectomy for treatment of pain associated with endometriosis. J Minim Invasive Gynecol 2006;13(6):566-72.[CrossRef]
10. Roman H, Moatassim-Drissa S, Marty N, Milles M, Vallee A, Desnyder E, et al. Rectal shaving for deep endometriosis infiltrating the rectum: a 5-year continuous retrospective series. Fertil Steril 2016;106(6):143845.e2.[CrossRef]

11. Roman H, Milles M, Vassilieff M, Resch B, Tuech JJ, Huet E, et al. Longterm functional outcomes following colorectal resection versus shaving for rectal endometriosis. Am J Obstet Gynecol 2016;215(6):762e1762e9.[CrossRef]

12. Meuleman C, Tomassetti C, D'Hoore A, Van Cleynenbreugel B, Penninckx F, Vergote I, et al. Surgical treatment of deeply infiltrating endometriosis with colorectal involvement. Hum Reprod Update 2011;17(3):311-26.[CrossRef]

13. Lagana AS, Vitale SG, Trovato MA, Palmara VI, Rapisarda AM, Granese $R$, et al. Full-thickness excision versus shaving by laparoscopy for intestinal deep infiltrating endometriosis: rationale and potential treatment options. Biomed Res Int 2016;2016:3617179.[CrossRef]

\title{
口다맘 \\ OLGU SERISI-ÖZET \\ Turk J Surg 2019; 35 (4): 325-328
}

\section{Endometriozis için kolon rezeksiyonu}

\author{
Timuçin Erol ${ }^{1}$, Erhan Reis ${ }^{2}$, Önder Koç ${ }^{3}$, Barış Taşbaş ${ }^{4}$ \\ ${ }^{1}$ Hacettepe Üniversitesi Tıp Fakültesi, Genel Cerrahi Anabilim Dalı, Ankara, Türkiye \\ ${ }^{2}$ Memorial Ankara Hastanesi, Genel Cerrahi Bölümü, Ankara, Türkiye \\ ${ }^{3}$ Memorial Ankara Hastanesi, Kadın Hastalıkları ve Doğum Bölümü, Ankara, Türkiye \\ ${ }^{4}$ Liv Hospital, Radyoloji Bölümü, Ankara, Türkiye
}

\section{ÖZET}

Endometriozis doğurganlık çağındaki kadınları etkiler ve fonksiyonel bozukluklara yol açabilir. Bazen hastalığın sınırları genel cerrahi yönünden müdahale etmeyi gerektirebilir. Özellikle yakın komşuluk nedeniyle sigmoid kolon ve rektum etkilenebilir. Böyle bir durumda tedavi hasta ve semptomlar göre bireyselleştirilmelidir. Lezyon tüm bağırsak duvarını penetre etmiş ise bağırsak rezeksiyonu kaçınılmaz olabilir. Laparoskopik sigmoid kolon ya da rektum rezeksiyonu bu durumda güven ile yapılabilir. Teknik zorluklar nedeniyle laparoskopik rezeksiyonun mümkün olmadığı durumlarda ise tedavi için açık rezeksiyon yapılabilir. Burada, endometriozis nedeniyle biri açık biri laparoskopik olarak yapılan kolon rezeksiyonu olguları sunulmaktadır.

Anahtar Kelimeler: Endometriozis, kolon rezeksiyonu, histerektomi

Doi: $10.5578 /$ turkjsurg.4054 